\title{
In Search of Biblical Role Models for Mongo Women: A Bosadi Reading of Vashti and Esther
}

\author{
MALEKE M. KONDEMO (UNIVERSITY OF STELLENBOSCH)
}

\begin{abstract}
The Old Testament world clearly subjected the woman to the will and protection of her husband, but she was also celebrated for performing important roles as wife and mother. Although some of its texts may be considered oppressive in certain ways, the Bible also contains positive examples of liberation stories for women to emulate. The Bible contains stories which may be read to promote the rights of women to be what God wants them to be, a right which needs to be reclaimed. Informed by David Adamo's African biblical hermeneutical reading that encourages the appropriation of the Bible by African women and men by reconsidering ancient biblical traditions and African life experiences with the purpose of finding biblical role models, this essay reads the Bible from the point of view of the marginalised and oppressed in order to draw out a liberation message. In this article, I examine the characters of Esther and Vashti in the book of Esther as they navigate a patriarchal context in light of Mongo women's experiences. Though Esther and Vashti operated on a high-class level, both women can serve as role models to Mongo women. The strategies used by the two queens can also be combined to affirm Mongo women and help them to conceive new identities and roles. ${ }^{1}$
\end{abstract}

KEYWORDS: Ruth, Esther, Woman, Bosadi, Old Testament, Wife, Mongo, Democratic Republic of Congo

\section{A INTRODUCTION}

The issue of women's subordination is a global phenomenon which wears different faces and appears in different degrees in some parts of the world. Thus, contrary to appearances, women's subordination is not peculiar to Africa or to the Mongo society. The quest for women's own identities and self-definition

\footnotetext{
* Submitted: 28/04/2021; peer-reviewed: 14/09/2021; accepted: 17/09/2021. Maleke M. Kondemo, "In Search of Biblical Role Models for Mongo Women: A Bosadi Reading of the Characters of Vashti and Esther," Old Testament Essays 34 no. 2 (2021): 554 - 572. DOI: https://doi.org/10.17159/2312-3621/2021/v34n2a14.

1 The main content of this paper is extracted from Chapter Five of my thesis entitled: "In Search of Affirming Identities and Role Models: A Gender-Sensitive Rereading of the Vashti and Esther Characters in the Book of Esther among the Mongo of the Democratic Republic of the Congo" (DTh thesis, University of South Africa), 2015.
} 
continues to raise much debate in all aspects of life in the Democratic Republic of the Congo (DRC). Issues of identity are crucial today as identities of the Congolese in general and the Mongo in particular are mainly defined along sexual lines (that is, male/female) or in gender terms (that is, masculine/feminine). Regardless of a woman's role and position, the focus is ultimately on her sex. Respect and consideration for her depend on her gender and are in relation to a man. Women in many countries have risen up to speak for themselves and this has led to great advancement in the fight for human rights as well as the rights of women and children. Some strides have been made in the area of gender equity and women have begun to attain a higher level of visibility.

However, in the DRC especially among the Mongo of the Equatorial Province, women are still far behind when it comes to equal rights and representation. Most Congolese women remain bound to the patriarchal norms that define them. Mwaura notes that in both private and public spheres, the roles and images of African women are defined socially and culturally by men. ${ }^{3}$ African culture is marked by various practices that dehumanise women such as taboos that guide food, relationships, widowhood rites, child betrothals and early marriages, domestic and cultural violence, female genital mutilation and lack of access to and control of family or even sometimes national resources. Thus, various cultural practices have been used to silence many women and prevent them from claiming their right and living a dignified life.

Making "African social context a subject of interpretation"4 and informed by experiences of African people, Adamo uses the African biblical hermeneutical approach to interpret the Bible. Following that approach, this study brings two contexts, that is, the Mongo context and the Esther and Vashti context into dialogue to promote the liberation and affirmation of Mongo women's identities. Hence, to reread the Esther and Vashti character, I appropriate the bosadi (womanhood) approach developed by the African-South African biblical scholar Madipoane Masenya (Ngwan'a Mphahlele) ${ }^{5}$ to reread the Esther and Vashti character in the book of Esther. The concept of bosadi is particularly interesting, as it is rooted in the context of African peoples and seeks to redefine what it means to be a woman in that particular context. The bosadi framework also problematises and challenges oppressive traditional definitions and roles of women, while affirming definitions, identities and roles which are

3 Philomena N. Mwaura, "Feminist Biblical Interpretation and the Hermeneutics of Liberation: An African Woman's Perspective," in Feminist Interpretation of the Bible and Hermeneutic of Liberation (JSOTSup 374; ed. S. Schroer and S. Bietenhard; Sheffield: Sheffield Academic Press, 2003), 79.

4 David T. Adamo, Reading and Interpreting the Bible in African Indigenous Churches (Eugene: Wipf and Stock=, 2001).

5 Madipoane Masenya (Ngwan'a Mphahlele), "Struggling to Find 'Africa' in South Africa: A Bosadi (Womanhood) Approach to Biblical Texts," SBL Forum, Online: http://www.sbl- site.org/publications/article.aspx?articleId=402 
positive. It also problematises and challenges oppressive traditional definitions and roles of women while affirming definitions, identities and roles which are positive. Bosadi, which is clearly an African biblical hermeneutical approach, will help to identify and consider parallels between the characters of Vashti and Esther and the Mongo women of the DRC today.

As one of the books named after a woman, the book of Esther points to two different roles by influential women that call attention to women's rights. The book focuses on woman's role as a wife who is expected to be obedient and submissive to her husband and go to any length to save her family, a role that Vashti failed to assume as did Esther. The book of Esther clearly illustrates both the blessing and the curse of womanhood. Esther is said to be a pawn in the hands of the book's male narrator. She is portrayed as a woman who acts to achieve patriarchal norms, while Vashti is portrayed as a disobedient wife. How are Esther and Vashti characters read and interpreted in the Mongo context? Which reading emerges if the bosadi approach is employed in one's engagement with the two characters? How can Mongo women be enriched by the stories of these two women in their search for new roles and identities? The discussion which follows will focus on how women identify themselves with the two characters and on the message that both characters convey to women which could promote either their liberation or intensify their actual situations. The discussion will also attempt to offer a fresh way of reading the text which in my view can empower women.

\section{B WOMEN IN MONGO PATRIARCHAL SOCIETY}

A Mongo woman plays various roles - as a daughter, a sister, a wife and a mother. At puberty, girls are taught to understand their bodies and womanhood. Women nurture their children and guide their own daughters into womanhood and motherhood. The education of children especially daughters is the primary responsibility of mothers. The society assigns mothers the role of preparing daughters for motherhood. They do this by assigning domestic chores to their daughters. Obbo observes that it is in the kitchen, around the fire, that traditions are transmitted to future generations. ${ }^{6}$ Among the Mongo, as in many other parts of the DR Congo, a woman's main role is to get married and produce children. According to Boni, the society ascribes roles to each sex. Society and culture define women's social role primarily as a caregiver and caretaker as well as in terms of reproductive functions whereas men are regarded as breadwinners and are defined by their productive abilities. ${ }^{7}$

6 Christine C. Obbo, African Women: Their Struggle for Economic Independence (London: Zed Books, 1980), 14.

7 Tanella Boni, Que devient les femmes d'Afrique? (Paris: Edition du Panama, 2008), 41. 
Marriage is considered important in the Mongo society in religious, social, economic and political circles. On the moral level, marriage is a sign of stability and commitment. A girl child who has committed herself shows good conduct and thus gains a good reputation. Her marriage bestows honour on her and her family. On the social level, marriage conveys some status on a woman. The Congolese believe that a woman only becomes a real woman after marriage. Due to poverty, young women are forced into marriage especially to wealthy men to ensure that their families survive. Once married, no matter what she can experience, a woman must do anything under her power to make her marriage work because of the cultural beliefs and the Christian tradition. It does not matter whether she is a second or third wife, what matters is that she belongs to a man who can provide for her and her family. Therefore, she must be submissive to the man at all costs to preserve her place and that of her family through marriage.

The role of a woman as a wife and a mother is considered of great importance by the Mongo. The good wife stays at home as her operation outside the home is a source of concern to her husband. Therefore, professional women are further trapped by the double standards that are used to distinguish between good and bad women. ${ }^{8}$ Women who engage in professional work or who are well educated are sometimes regarded as bad. These women are often portrayed negatively because they have difficulty relating to patriarchal norms which reserve the domestic sphere for women while the public domain remains the preserve of men. Therefore, such women often have to keep their marriage intact - through thick and thin. ${ }^{9}$ In the Mongo society, a woman's identity is closely related to her capacity to produce children. This ideology of motherhood is so widespread that what is natural (the capability to procreate) now takes a cultural dimension. In fact, for the Mongo, a woman cannot afford to be unproductive (childless) whether naturally or voluntarily.

As the mother of children, she is everyone's mother. The transition into motherhood confirms a woman's status in the community and ensures the numerical growth of the clan and the family. The roles of woman, mother and wife have important implications for women and contribute substantially to their subordination at home and in the public arena. Not only does the society but many women also (regardless of their positions) regard women as useless when they do not perform the role of wives and/or mothers in the society. When it comes to women's self-perception, it becomes clear that women define themselves based on the same patriarchal standards that are used to identify them as sisters, wives or mothers. Women's self-perceptions have often been shaped by these constructs. In spite of these roles which are sometimes disempowering,

8 Obbo, African Women, 15.

9 Mercy A. Oduyoye, "Reflections from a Third World Woman's Perspective: Women's Experience and Liberation," in Feminist Theology from the Third World: A Reader (ed. Ursula King; New York: Orbis Books, 1994), 166-181. 
women have developed new roles of authority and strength. However limited and ambiguous they seem; these identities differ from one woman to another. In my view, the highest honour a Mongo woman receives is as a mother.

\section{REREADING VASTHI AND ESTHER WITHIN THE MONGO CONTEXT}

Each generation reads the story of Esther differently and tends to assess the behaviour of its central characters according to the different ways the readers of that generation see the world around them and react to its ideas and values. In Esther, we see queens who attempted to counter the dominant male power structure when dehumanising acts are pursued. The two queens offer modern women examples of how to make realistic decisions in their own situations. Vashti the first queen asserted her dignity even though she ended up losing her crown. Esther the second queen effectively used traditional guile to save herself and her people. Gender-related issues therefore emerge strongly in the book of Esther. According to Niditch, "The book of Esther is about the status quo, maintenance of it, and finding a proper place within it. Vashti is regarded as a disobedient wife, a threat to the patriarchal society while Esther a model of a woman in a man's world." 10 The overall opinion of Vashti has tended to be negative. Many traditions criticise her quite harshly and see her behaviour and personality in negative terms while Esther is depicted positively. Esther has gone down as one of the greatest heroines in Jewish history and has received an almost overwhelmingly positive assessment. However, in the last generation and under the influence of feminist thinking, the scales have tipped in a different direction. Vashti is upheld by many as an example of proud dignified womanhood. She is celebrated as a woman who was prepared to pay the price for refusing to be humiliated by a hostile male world that wished to turn her into an ornament by ignoring her essential humanity.

Members of the Mongo society seem to be comfortable with the book of Esther as it appears to conform to the way the society is structured. Men are trained to be dominant while women are supposed to be submissive. Men have more power and women have less. Men are the active subjects, gaining their power by objectifying women. By paying the bride price, for example, women are presented as male property, possessions who are not valued for their character but for their beauty, sexuality (in the case of the prospects for a new queen) and youth. ${ }^{11}$ Women are expected to conform to the patriarchal norms to guarantee their success and survival. These norms are accepted as part of culture and are

10 Susan Niditch, "Short Stories: The Book of Esther and the Theme of Women as a Civilizing Force," in Old Testament Interpretation Past, Present and Future: Essays in Honor of Gene M. Tucker (ed. James L. Mays; Nashville: Abingdon, 1995), 33.

11 Sarojini Nadar, "Power, Ideology and Interpretation/s: Womanist and Literary Perspectives on the Book of Esther as Resources for Gender-Social Transformation." (DPhil thesis, University of Natal Pietermaritzburg, 2003), 42. 
reinforced by church traditions. Therefore, if the Bible especially the Old Testament is not read from a gender-sensitive viewpoint then we also endorse this behaviour.

The negative portrayal of Vashti has greatly influenced the interpretation of Vashti's character among Mongo Christians. In Christian tradition, for example, there is hardly any admiration for Vashti. Within some Congolese church, Vashti's character is depicted negatively and she is mentioned only in some sermons in contrast to Esther who is upheld as a model and is usually at the centre of such sermons. ${ }^{12}$ The image one derives of Vashti depends on one's starting point. Interpretations that are rooted in patriarchal views are often quick to assign as much blame and negativity to Vashti as to the king even when they try to excuse Vashti's refusal. Vashti's refusal means more today than it must have done in the past. Revisiting her character in our modern context leads to a new way of reading the Bible. As Tamez has observed, "A reading of the Scripture that truly liberates responds to the situation that has motivated the reading." $"$ It is only via such readings that we will begin to challenge the negative foundations and constructs of society in order to establish justice and change.

Queen Vashti is the example of a woman who does not submit to practices that contravene human dignity. In spite of her position as a queen in the royal court, the men around Vashti tried to control her. According to Masenya (Ngwan'a Mphahlele), ${ }^{14}$ the negative portrayal of Vashti by the narrator tempts one to speculate that she received such harsh treatment because she was a woman in a world that did not legitimise women's power. Vashti is an example of one whom though socio-economically and ethnically strong continued to be haunted by her gender. Thus, one agrees with Sakenfeld that even in the midst of wealth, women still struggle as Vashti did. ${ }^{15}$ The royal court, which is a place where the law should be respected and life should be preserved, is often re-enacted today within the home. To survive, women are forced to be obedient and submissive at all costs. Women's lives and bodies are controlled and used sometimes against their wishes by men. They are forced to go through inhuman practices such as

12 I draw this from my personal experience. Several times, I have listened to Sunday sermons or women's seminars on Esther by women. Esther is usually at the centre of the sermon, and she is praised as a perfect woman, a wife who gained her husband's favour because of her obedience in contrast to Vashti who is depicted as a bad wife who destroyed her marriage through her disobedience.

13 Elsa Tamez, "Women's Reading of the Bible," in Feminist Theology from the Third World: A Reader (ed. Ursula King; New York: Orbis Books, 1994), 190.

14 Madipoane Masenya (Ngwan'a Mphahlele), "A Small Herb Increases Itself (Impact) by a Strong Odour: Reimagining Vashti in Esther in an African-South African Context," Old Testament Essays 16/2 (2003): 332-342.

15 Doob K. Sakenfeld, Just Wives? Stories of Power and Survival in the Old Testament and Today (Louisville: John Knox Press, 2003), 63. 
female genital mutilation and body transformation to satisfy men. However, men do not control only women; they also control fellow men that are weaker or inferior to them in some ways. ${ }^{16}$

Esther is presented at first as the perfect foil to Vashti. Whereas Vashti was wilful and independent, Esther was passive and submissive. She was a model of docility, a contrast to Vashti. Esther is the main biblical character who offers Mongo women a model of hope and faith. To them, Esther is a woman whose commitment to God is rewarded by the blessing of not only becoming the wife of the king but also of becoming the saviour of her nation. Like Hannah, Esther is regarded as a model woman who having spent time with God was given everything she required. Esther becomes to these women the model of a strong and faithful woman - a model of hope, a woman who even though she was in a foreign land, enjoyed the privilege of becoming a queen. Crawford argues that,

With no native power of her own owing to her sex or position in society, Esther must learn to make her way among the powerful and to co-operate with others in order to make herself secure. She uses whatever mean are available for her to survive in such an environment where the laws of the king are irreversible. Even though her actions can be criticised for not being revolutionary, Esther shows how one can transcend class boundaries without being thrown out of the system completely. ${ }^{17}$

Esther was a victim of her situation in the sense that, as a woman in a maledominated patriarchal world, she had to be careful about what she did or did not do and what she sought to achieve. Esther had to conform to the rules in order to play the most respectable and expected role of a woman in the patriarchal society - the role of a wife.

Within the church, Esther is a popular biblical character along with other female figures such as Ruth, Hannah and Deborah who inspire hope in women. Esther is viewed as a woman who remained humble and obedient in the midst of the suffering of her people and who finally obtained what she wanted. She was a self-sacrificing woman who was also full of compassion. Esther is one of those biblical books that women claim as their own since it is a story of hope. The narrative speaks to the experiences of women especially in contexts where women are oppressed and have no place in society. In such situations, prayer and the hope of God's intervention in a hidden way offer the only hope for a better life. Esther is held as an example of a woman who was committed to God, who

16 Kondemo, "In Search of Affirming Identities," 164.

17 White S. Crawford, "Esther: A Feminine Model for Jewish Diaspora," in Gender and Difference in the Ancient Israel (ed. Lynne P. Day; Minneapolis: Fortress Press, 1989), 167. 
waited for God's directives before taking any action. In the church context, she is seen as a wise woman who sought God first, before taking any decision. ${ }^{18}$

On the one hand, many gender-sensitive readers particularly those of Christian persuasion regard Vashti as an example of a proud dignified woman who was prepared to pay the price of refusing to be humiliated by a hostile male world that wished to turn her into an ornament, ignoring her humanity. Such readers elevate Vashti as the heroine of the book. The above interpretation of Vashti as a victim of a powerful male resonates well with the gender interpretations of this story which also portray Esther as a victim. The second reading or interpretation of this text portrays Esther as a seductress, as we shall see below. According to the narrative, Vashti is banished not because of her disobedience but because of the possible effects that her action would have on other less powerful women who would follow her lead to disobey their husbands. Vashti is regarded as a revolutionary and through her action she was able to show the men that a woman too has a will. ${ }^{19}$

On the other hand, a reading that would be popular among the Mongo would show Vashti as a villain. Instead of seeing her refusal as the result of her self-esteem, proponents of such a reading see her as one who thought she was better than everyone else and who defied Ahasuerus' command because of pride. The reasoning here is that Vashti's refusal was intended to humiliate her husband in front of his guests. She was a disobedient wife who, though enjoyed the privileges of the kingdom, ignored her responsibilities. The Bible does not explain the reason for Vashti's refusal but in the Mongo context, as a wife, Vashti would be expected to respond to the king's call first before expressing her opinion. Her action led not only to her downfall but also to a more repressive regime that mandated all women in the empire to obey their husbands' whims. In such a context therefore, Vashti is not regarded as a good model since she did not act as a good example for other women to follow. How then could both Vashti and Esther serve as a model for Mongo women? ${ }^{20}$

\section{VASHTI AS A MODEL OF WOMEN'S RESISTANCE}

Vashti, the Queen of Persia and the first woman introduced to readers in Esther is seen as a disobedient wife who refused to appear when her husband summoned her. Her story is seldom remembered in our congregations. Church members talk about Vashti only in passing as though she is not part of the Esther narrative. Many argue that Vashti only served to pave the way for Esther, one of the main actors in the story, to appear. However, the short story of Vashti presents a background that outlines in detail the symbolism of power as personified by the actions of the king and his advisors. It also outlines the absolute power of the

18 Kondemo, "In Search of Affirming Identities," 209

19 Ibid., 194.

20 Ibid., 195. 
male ruling class and how it deals with those who dare to disobey, regardless of what drives them to do so. ${ }^{21}$

Although Christian doctrines have been used to subordinate women in many ways, in some denominations, they have been used also to legitimise women's voices and claim to spiritual (if not social) equality. The men in the ancient patriarchal society described in the book of Esther, in particular the king and his advisors, were certainly insecure. Vashti was portrayed as a negative role model with whom a man would not want his wife to associate lest she be encouraged to think for herself and refuse to be paraded before her husband's drunken friends at the next party. Beal remarks that, "Vashti is the supplement that Esther requires. Her erasure marks on Esther's character re-member the extremes to which this ridiculous patriarchy will go in order to maintain itself and the extreme to which each woman must go to resist it."22 By her refusal, Vashti maintained herself as the agent of her own action. Thus, she confronted the abusive male power structure.

Vashti's refusal represents a courageous act in the face of a maledominated society, yet the king's response makes the men's position in that society look tenuous at best. However, this brief event of Vashti's resistance set the stage for Esther and her future manipulation of the king, showing that patriarchy is strengthened only when women encourage it. In her discussion of the origins of patriarchy, Lerner makes an observation about the role of women which sadly is still applicable in the twenty-first century:

The system of patriarchy can function only with the cooperation of women. This cooperation is secured by a variety of means: gender indoctrination; educational deprivation; the denial to women of the knowledge of their history; the dividing of women one from the other, by defining 'respectability' and 'deviance' according to women's sexual activities; by restraints and outright coercion; by discrimination in access to economic resources and political power; and by awarding class privileges to conforming women. ${ }^{23}$

As noted above, patriarchy cannot function without women's support. Women have helped men to perpetuate patriarchal norms in all generations. Therefore, Vashti's behaviour was regarded as a violation of the order of things in the society. All the Persian officials became emotional and scared that a women's revolution might destabilise the household and family life. Through

21 Bea Wyler, "Esther: The Incomplete Emancipation of a Queen," in A Feminist Companion to Esther, Judith, and Susanna. The Feminist Companion to the Bible 7 (ed. Athalya Brenner; Sheffield: Sheffield Academic Press, 1995), 115.

22 Timothy K. Beal, "Esther," in Studies in Hebrew Narrative and Poetry (ed. D.W. Cotter; Minnesota: The Liturgical Press, 1996), 106.

23 Gerda Lerner, The Creation of Patriarchy (Vol. 1; Oxford: Oxford University Press, 1986), 217. 
Vashti however, Persian men recognised female power of which men are often ignorant. Vashti speaks for the powerless and those disenfranchised by gender, race, sexual orientation, or any other index on which the powerful build exclusion. Vashti was confronted with what she considered an injustice, but she refused to participate in her own oppression. She knew her rights as a full human being and refused to allow anyone to deny her such rights. She was an individual who simply said 'No' to society's expectation and evaluation of her. She was a strong-willed character with an independent mind whose courage is admirable. Vashti indeed refused to heed the king's request because she deemed it degrading. Thus, she can be regarded as a principled and forthright person, a model to anyone who chooses to follow his or her conscience regardless of the cost. $^{24}$

Seeing Vashti as a model of female resistance remains a challenge in the Mongo context even though others may hold a different opinion. On the one hand, Vashti's defiance of her husband cannot be appropriated as the quality of a God-fearing woman. What feminists have regarded as boldness, independence or courage on the part of Vashti might be interpreted as folly, carelessness and defiance by many Christian women who continue to yearn for a God-fearing kind of relationship with their husbands. Understandably, for such women, Vashti cannot serve as a model of survival in an environment which continues to ostracise them through factors such as patriarchy, poverty, ethnicity, and race, among others. ${ }^{25}$ For centuries, Vashti has been considered by many as a model of female resistance through her action, as she resisted her husband by refusing to be paraded in front of him and his guests. Therefore, as argued by Masenya, many women who are socially disadvantaged may also find it difficult to emulate Vashti or see her as a model of resistance because of her social class. Vashti was a woman who operated from a high level. ${ }^{26}$ Thus, appropriating the character of Vashti as a model within the Mongo context, would not be easy for many Mongo women who find hope only within marriage.

However, Vashti's refusal can serve as a starting point for women as well as men to resist wrongdoing in the society. Regardless of a woman's position in the society, keeping silent and accepting their situation is not always a solution. In certain situations, people need to stand up against what they perceive to be immoral or unjust and uphold justice regardless of the consequences. Freedom can prove to be expensive but there are moments in life when enduring oppression in whatever guise is no longer an option and one would rather pay that price. At such turning points, one can only maintain personal integrity by

24 Linda M. Day, "Esther," Abingdon Old Testament Commentaries (Nashville, TN: Abingdon Press, 2005), 42-43.

25 Masenya (Ngwan'a Mphahlele), “A Small Herb Increases Itself,” 332-342.

26 Ibid., 341. 
standing up to take risks. ${ }^{27}$ Vashti valued herself as a woman and her identity as a human being was more important to her than her position as queen. Vashti becomes a symbol of resistance and of recapturing one's voice, ironically, by not speaking at all. Several cases are reported in the DRC in which people (men or women) have said 'No.' Examples that come to mind are those of Beatrice Kimpa Vita who stood against colonialism and Saint Anuarite who refused to lose her virginity. They lost their lives because they refused to cooperate with the system and chose to protect their dignity as women. ${ }^{28}$ These women could serve as an inspiration for Mongo women even though they are forgotten by the society.

Some women have said 'No' to abusive marriage and to the objectification of women even at a great cost while others who have said 'No' to harassment at work have lost their jobs. To resist marginalisation and oppression, one must be prepared to pay the price. Even if we sometimes do not immediately reap the fruit as in the case of Vashti, those who come after us can benefit from our actions as did Esther who married a transformed king. Though Vashti was banished from the king's presence, he learned something from her that gave Esther the freedom to manipulate him. One agrees with Sakenfeld ${ }^{29}$ that saying 'No' should be possible for women and men alike. Irrespective of one's social status or standing in life, women should be able to resist marginalisation and any injustice perpetrated against them in the society and within their marriage. Vashti seemed to know what she wanted, and she did what was needed to achieve her goal irrespective of the repercussion.

\section{E ESTHER AS A MODEL OF WOMEN'S SURVIVAL IN A MAN'S WORLD}

Esther is one of the treasured stories of the Bible which is loved by any young girl who dreams of a life like that of the beautiful Persian Queen. It is a fascinating story, a story of love. However, Nadar ${ }^{30}$ shows that, "Women in our church usually have to choose between Vashti and Esther. Given the negative way Vashti is presented, they usually have no choice but to choose in the same way the king has chosen Esther as the better woman." Esther is portrayed as a model with whom women should identify, a submissive and obedient wife. Vashti who was disobedient lost her position but Esther is regarded as a model of a strong and good wife. She is portrayed as a faithful, self-sacrificing woman who would sacrifice her life to save her nation from destruction.

\footnotetext{
27 Day, "Esther," 43.

28 Kondemo, "In Search of Affirming Identities," 203.

29 Sakenfeld, Just Wives?, 64.

30 Sarojini Nadar, "Gender, Power, Sexuality and Suffering Bodies in the Book of Esther: Reading the Characters of Esther and Vashti for the Purpose of Social Transformation," Old Testament Essays 15/1 (2002): 124-125.
} 
The portrait of Esther is mixed. In a difficult situation, she used what she had been given by nature. At the same time, she learnt from her tradition and heritage to use her power and natural resources in tandem with the community's own belief. Unlike Vashti who refused to be a sexual object and her husband's toy, Esther is the stereotypical woman in a man's world. Reading the character of Esther with a womanist eye, Nadar ${ }^{31}$ sees Esther's ascension to the throne as baying to the patriarchal game. To keep her favour and her position, Esther conformed so well to the system that she used her power in an abusive way to kill innocent people. In Crawford's ${ }^{32}$ view, Esther adapted to gender expectations, working within the privacy of home and never exercising any kind of public authority. Crawford balances the tension in scholarship over Esther's classification. She regards Esther as a typical woman in terms of gender but also recognises that gender may signify larger political realities of powerlessness. Thus, from her perspective, one cannot evaluate the degree to which Esther conforms to gendered expectations.

Day $^{33}$ recognises the different methods employed by the two queens. She notes that Esther distinguished herself from her predecessor Vashti and Vashti's way of doing things, showing a different type of female leadership. The differences in the actions of the two queens remind the reader that there is never one right way to exert influence. Leadership styles can legitimately vary according to individual personality and talent. It appears that Esther had seen how the first queen conducted herself when under pressure and decided that Vashti's style would not be suitable for her. Acting instead according to her own wisdom and intuition, she successfully accomplished her goal. To get what she wanted, Esther played her game according to men's rules. It will be erroneous to view Esther as the prototype of an ideal woman. She obtained favour based on her physique and beautiful appearance as a woman in a man's world and then by her ability to satisfy the king sexually.

Different scholars have criticised Esther for choosing to display herself before the king when Vashti refused to do the same. Esther responded positively to the male gaze. This is certainly true in Esther 2 but we do not know how much choice Esther had with regard to her role in the harem. If one assumes that she was forced to parade herself, then, Esther did not have much choice but to use

31 Sarojini Nadar, "Text of Terror. The Conspiracy of Rape in the Bible, Church, and Society: The Case of Esther 2:1-18," in African Women, Religion and Health. Essays in Honor of Mercy Amba Ewudziwa Oduyoye (ed. A.I. Phiri and S. Nadar; Pietermaritzburg: Cluster Publication, 2006),86.

32 White S. Crawford, "Esther and Judith: Contrasts in Character," in The Book of Esther in Modern Research (ed. W.S. Crawford and L.J. Greenspoon; London: T\&T Clark International, 2003), 61-76.

33 Day, "Esther," 101. 
whatever power was available to her to survive in the patriarchal system. Fox ${ }^{34}$ argues that Esther had no choice at all because all comely virgins were gathered; there was no further selection before they were taken to the king. In any case, the Persians have already proved themselves intolerant of female freedom of choice. Esther used her beauty to a certain extent to get what she wanted. She knew what her beauty meant to Ahasuerus a powerful king who could create a national crisis when he realised that he did not fully own his wife's body. Esther won her victories precisely because she possessed the necessary skill and character.

While on the surface, the central theme in the book of Esther appears to be that of the story of the Jewish people, in the light of the centrality of the female characters in the story, the theme may really be about their survival as women in a patriarchal world. Esther very cleverly shows that it is possible to break this hierarchy characterised by discrimination based on gender, socio-economic class and ethnicity. Unlike Vashti who chose public protest that aggravated male fear, Esther chose to confront her situation in a very different way. Esther chose a nonconfrontational and non-violent model. She took counsel from others and spoke up to save her people but she also served the king's interests. Esther reminds us not to avoid challenges or be comfortable in our own fortified palace but to take responsibility and ask others to do the same. She is the model of a woman who chooses to stand and use every means at her disposal to save others even at the risk of her own life. What matters most were her family and national interests. Esther had the heart of an African mother who does not only care about her own family but the needs of the whole village. Esther can be identified with many responsible women in the way she acted in times of crisis.

Esther was a woman who worked within the patriarchal system of her time. She used intrusion to penetrate the system without being discovered. We are told that even her husband the king was not aware of her origin (Esth 2:10). King Ahasuerus and his servants were ignorant of her game plan and of her family and origin. Esther was an intelligent woman. First, having been raised by a man, Esther got accustomed to the Persian patriarchal system from childhood. Second, she learnt the Persian culture and way of life. Being married to a Persian king, Esther was automatically assimilated into the Persian culture. Her identity changed from that of a young virgin in the harem to Ahasuerus' wife and Persian queen. From Vashti's behaviour and fate, Esther learned how to operate in the system in which she found herself. Vashti failed in using her power, as such, her single action brought punishment on all women. Esther though, chose diplomacy. She chose not fight power with another form of power. She fought

34 Michael Fox, Character, and Ideology in the Book of Esther (2nd ed.; Grand Rapids: William B. Eerdmans, 1991), 197. 
the system and the person who was responsible for upholding the patriarchal norms in a different way.

Viewed from the bosadi perspective, Esther can only be partially regarded as a liberating model for women in their search for affirming identities. On the one hand, Esther does serve as a role model for the values that she demonstrates. However, she is not a character that ordinary people would emulate because her actions are exceptional, brought on by extreme necessity rather than everyday situations. As already argued, Esther was a wise woman. She knew how to strategise and create opportunities. She used not only her femininity but also her brain to get what she wanted. She did not use a violent or aggressive method since she understood that aggression would not be effective in dealing with the king and his servants. She avoided falling into the same pit as Vashti. Her first wish was to be heard and understood. She made the king to listen to her anxieties and made him to act accordingly. Esther was patient; she waited for the right time to take action. She did not go, as the Mongo would say, like ngulu ngulu (literally a pig, which means one who does things without thinking first or having any plan). Esther had a well thought out plan, proving that women have many gifts that can be used to change their situation in a peaceful way.

Like today's Mongo woman, Esther remained attached to her family and nation even though she was married to a Persian king. Her knowledge of the system however helped her to succeed in her plan to save her nation. Therefore, upholding Esther, her character and her wisdom as a model could prove helpful to Mongo women. Although her method of finding solution to a problem by using her body should be challenged, Esther remained a woman, a daughter and a wife. She did not change her identity by becoming a man or acting as a man would do but used her position and her identity as a wife to change her situation. She engaged with and listened to those around her - her maids, Mordecai, the messengers - before taking the action which led to her success.

\section{F IN SEARCH OF BIBLICAL ROLE MODELS FOR MONGO WOMEN}

If faced with the choice between Esther and Vashti, Mongo women are likely to choose Esther over Vashti. Traditionally, Esther is seen as the model of a Jewish woman in an oppressed society who used her beauty and position to save her people from a decree of death. She served as a model of hope and revolution for people in times of crisis. However, like Fuchs ${ }^{35}$ and Laffey, ${ }^{36}$ Gendler also prefers Vashti to Esther as he argues:

35 Esther Fuchs, "Status and Role of Female Heroines in the Biblical Narrative," in Women in the Hebrew Bible: A Reader (ed. A. Bach; New York: Routledge, 1999), 82. 36 Alice L. Laffey, An Introduction to the Old Testament: A Feminist Perspective (Philadelphia: Fortress Press, 1998), 216. 
What about Esther do I find objectionable? In most ways she sounds like an ideal woman - beautiful, pious, obedient, courageous. And it is just this which I find objectionable. Esther is certainly the prototype- and perhaps even a stereotype - of the ideal Jewish woman, an ideal which I find restrictive and repressive. ${ }^{37}$

Thus, Esther is found lacking as a model of female liberation. She is further criticised for achieving success by fulfilling only traditional gender roles. Esther's power was born out of her relationship to men; her access to the king was possible because she was his wife. However, from a bosadi perspective, the criticism in that regard can be challenged. Throughout the Bible, both men and women obtained power by birth, adoption or marriage. Men also obtained certain privileges through their lineage and/or marriage. For example, David's marriage to various women gave him some privileges and access to political strategy to help consolidate his power base. His marriage allowed him to contract alliances with other nations to settle his power. Moreover, there are instances when privilege was conferred on individuals not only because of their father but also because of their mother especially in cases where there were multiple wives. Thus, Jacob favoured the sons of Rachel, his favourite wife (Gen 37:3) and Solomon gained access to David's throne through the machinations of his mother Bathsheba (1 Kgs 2). It is important then to recognise the centrality of familial relationships and their impact on family dynamics and the political scene in order to appreciate the roles that both men and women play in private and public spheres.

Compared to Vashti, it seems Esther endured more difficult situations. Whereas Vashti refused to please the king, Esther complied. Whereas Vashti walked out of the system, Esther rushed in. Whereas Vashti defended her identity as a woman, Esther hid her own identity and passively complied with the system. The story points to the victory of pragmatism (Esther) over ideology (Vashti). It points to Esther's success. Esther not only saved the Jews, she ended up with more real power than Vashti would ever have had. By comparison, the story thus points to Vashti's failure. Vashti's goal of defending and promoting her ego and social status may not be different in principle from Ahasuerus, while Esther was not interested in self-aggrandisement but in helping her people. On the whole, feminists' views tend to dethrone Queen Esther and re-crown Queen Vashti. Although Vashti and Esther never met, the relationship between them is integral to understanding the events in the book of Esther. Vashti disappears by the end of the first chapter, but she casts a long shadow over the rest of the book.

Two characters Vashti and Esther are diametrically opposed and equally unappealing. Many commentators have noted that we are supposed to read the stories of each of these two figures in the light of the other. Vashti's refusal to

37 Mary Gendler, "The Restoration of Vashti," in The Jewish Woman (ed. E. Koltun; New York: Schocken, 1997), 242. 
expose herself and appear before the king led to her tragic fate. By contrast, Esther's (s) heroism lies in the very act of doing what Vashti refused to do - to appear before the king. What she did do was to hide her true self, a stance that came at a great price. In recent years, a fascinating debate has emerged about these two female figures. Which figure should we take as a role model for women in their struggle for emancipation? Were their actions the only two choices available to women in the ancient world? In recent times, Vashti's assertive nature has been elevated. Vashti is seen as a courageous woman. Her character is more appreciated than Esther's who is regarded as an instrument in a man's hands. Esther is said to be a woman who gave away too much; she paid too high a price for the sake of others. However, she remains a heroine - a model for many women in the church.

In his interpretation of the character of Esther, LaCocque ${ }^{38}$ shows that like Judith, Susanna and Ruth, Esther had to be covertly subversive in an oppressive patriarchal and ethnic context. Although Esther's character may not be regarded as revolutionary, there must have been important reasons why she chose not to rebel. One reason could be the lesson she learned from Vashti's banishment but the other could very well have been related to mortality given that the king could so arbitrarily endorse the genocide of an entire nation. At every stage of development, women are faced with a series of unacceptable choices. Can a liberated woman also possess modesty and restraint or are these possible only when she concedes to the demands of a man? The story of Vashti therefore cannot be erased. Her remarkable act of defiance which came at a great price resonates throughout the Bible. Vashti may be nothing but a prologue to the book of Esther in the eyes of the church but in the Bible, she lives on in the minds of her people, the king and, most importantly, Queen Esther herself. Esther however can serve as a model of hope and revolution for people living in dangerous times. White sees Esther as,

[A] model for the successful conduct of life in the often-uncertain world of the Diaspora. She compares Esther status as a woman to that of Jew in diaspora who become subordinate within a foreign empire, just as Esther, a woman, is subject to the dominant male. It is by accepting the reality of subordination position and learning to gain power by working within the structure rather than against it, the Jew could build a successful and fulfilling life. ${ }^{39}$

The story of Esther is about hope. It is not the conviction that a situation will turn out well but the certainty that it makes sense regardless of how it turns out.

38 Andre LaCocque, The Feminine Unconventional: Four Subversive Figures in Israel's Tradition (Overtures to Biblical Theology; Minneapolis: Fortress Press, 1990), 49-83.

39 Sidnie A. White, "Esther: A Feminine Model for Jewish Diaspora," in Gender and Difference in the Ancient Israel (ed. L.P. Day; Minneapolis: Fortress Press, 1989), 173. 
Therefore, we can act; we obey and disobey; we resist and fight for justice, not just for ourselves and our own but for all - because of hope, because it is what is true, what is human and what is God's will. It is in times like Esther's, a time such as ours when hope is threatened, that her story becomes a story for all peoples. It is a story that should give us the courage to stand firm and emulate Vashti's courage to reject oppression and abuse. Esther's story can help us to think first before taking action in certain situations. Assimilation does not always safeguard one from harm in times of crisis and keeping silent does not necessarily protect one from danger, yet they can help one to prepare oneself and have a better view of a situation before acting. Therefore, if strategies used by the two queens - Vashti by refusing to parade in front of drunken men to preserve her dignity and Esther by navigating through the system to reach her goal-are combined, they can be used by Mongo women to affirm new identities and roles.

\section{G CONCLUSION}

The narrative of Esther is that of two women who at first appear to be opposites in that one is portrayed as defying patriarchal norms while the other played according to the rules of the patriarchal game in an unequal society. However, the study of the two characters and their actions shows that they are not opposed to each other. Rather, they are complementary. Irrespective of their approach to the issues of their day, Vashti and Esther managed to transform their situations by challenging the norms. They took initiative within a patriarchal society and thus managed to change their lives "positively." Considering the ways in which women obtain favour and fight for survival, it has been shown that similarities exist in both the biblical and the Mongo contexts. Therefore, if read from the bosadi point of view, Vashti's and Esther's different ways of navigating situations, depending on one's reality, can be used by Mongo women to affirm their identities. Vashti demonstrated that she was capable of giving up everything to uphold her dignity while Esther used everything in her power for a common cause.

\section{H BIBLIOGRAPHY}

Adamo, David T. Reading and Interpreting the Bible in African Indigenous Churches. Eugene: Wipf and Stock, 2001.

Beal, Timothy K. "Esther." Pages 90-130 in Studies in Hebrew Narrative and Poetry. Edited by D.W. Cotter. Minnesota: The Liturgical Press, 1999.

Boni, Tanella. Que devient les femmes d'Afrique? Paris: Edition du Panama, 2008.

Crawford, White S. "Esther and Judith: Contrasts in Character." Pages 61-76 in The Book of Esther in Modern Research. Edited by W.S. Crawford and L.J. Greenspoon. London: T\&T Clark, 2003.

. "Esther: A Feminine Model for Jewish Diaspora." Pages 161-177 in Gender and Difference in the Ancient Israel. Edited by Lynne P. Day. Minneapolis: Fortress Press, 1989. 
Day, Linda M. "Esther.” Abingdon Old Testament Commentaries. Nashville: Abingdon Press, 2005.

Fox, Michael V. Character, and Ideology in the Book of Esther. 2nd ed. Grand Rapids: William B. Eerdmans, 1991.

Fuchs, Esther. "Status and Role of Female Heroines in the Biblical Narrative." Pages 77- 84 in Women in the Hebrew Bible: A Reader. Edited by Alice Bach. New York: Routledge, 1999.

Gendler, Mary. "The Restoration of Vashti." Pages 241-247 in The Jewish Woman. Edited by E. Koltun. New York: Schocken, 1976.

Kondemo, Marthe M. "In Search of Affirming Identities and Role Models: A Gender Sensitive Rereading of the Vashti and Esther Characters in the Book of Esther among the Mongo of the Democratic Republic of the Congo." DTh thesis, University of South Africa, Pretoria, 2015.

LaCocque, André. The Feminine Unconventional: Four Subversive Figures in Israel's Tradition. Overtures to Biblical Theology. Minneapolis: Fortress Press, 1990.

Laffey, Alice. An Introduction to the Old Testament: A Feminist Perspective. Philadelphia: Fortress Press, 1988.

Lerner, Gerda. The Creation of Patriarchy. Vol. 1. Oxford: Oxford University Press, 1986.

Masenya (Ngwan'a Mphahlele, Madipoane. "A Small Herb Increases Itself (Impact) by a Strong Odour: Reimagining Vashti in Esther in an African-South African Context." Old Testament Essays 16/2 (2003): 332-342.

. 'Struggling to Find 'Africa' in South Africa: A Bosadi (Womanhood) Approach to Biblical Texts." SBL Forum (2005).

http://www.sbl- site.org/publications/article.aspx?articleId=402.

Mwaura, Philomena N. "Feminist Biblical Interpretation and the Hermeneutics of Liberation: An African Woman's Perspective." Pages77-85 in Feminist Interpretation of the Bible and Hermeneutic of Liberation. Edited by S. Schroer and S. Bietenhard. JSOTSup 374. Sheffield: Sheffield Academic Press, 2003.

Nadar, Sarojini. "Gender, Power, Sexuality and Suffering Bodies in the Book of Esther: Reading the Characters of Esther and Vashti for the Purpose of Social Transformation." Old Testament Essays 15/1(2002): 113-130.

. "Power, Ideology and Interpretation/s: Womanist and Literary Perspectives on the Book of Esther as Resources for Gender-Social Transformation." DPhil thesis, University of Natal Pietermaritzburg, 2003.

. "Text of Terror. The Conspiracy of Rape in the Bible, Church, and Society: The Case of Esther 2:1-18." Pages 77-95 in African Women, Religion and Health. Essays in Honor of Mercy Amba Ewudziwa Oduyoye. Edited by Apawo I. Phiri and Sarojini Nadar. Pietermaritzburg: Cluster Publication, 2006.

Niditch, Susan. "Esther: Folklore. Wisdom, Feminism and Authority." Pages 26-46 in A Feminist Companion to Esther, Judith, and Susanna. The Feminist Companion to the Bible 7. Edited by Athalya Brenner. Sheffield: Sheffield Academic Press, 1995.

Obbo, Christine. African Women: Their Struggle for Economic Independence. London: Zed Books, 1980.

Oduyoye, Mercy A. "Reflections from a Third World Woman's Perspective: Women's Experience and Liberation." Pages 166-181 in Feminist Theology from the Third World: A Reader. Edited by Ursula King. New York: Orbis Books, 1994. 
Sakenfeld, Doob K. Just Wives? Stories of Power and Survival in the Old Testament and Today. Louisville: John Knox Press, 2003.

Tamez, Elsa. "Women's Reading of the Bible." Pages 190-201 in Feminist Theology from the Third World: A Reader. Edited by Ursula King. New York: Orbis Books, 1994.

White, Sidnie A. "Esther: A Feminine Model for Jewish Diaspora." Pages 161-175 in Gender and Difference in the Ancient Israel. Edited by Peggy L. Day. Minneapolis: Fortress Press, 1989.

Wyler, Bea. "Esther: The Incomplete Emancipation of a Queen." Pages 111-135 in A Feminist Companion to Esther, Judith, and Susanna. The Feminist Companion to the Bible. Edited by Athalya Brenner. Sheffield: Sheffield Academic Press, 1995.

Dr Maleke Marthe Kondemo, Postdoctoral Fellow Gender Unit, Department Old and New Testament, Faculty of Theology, Stellenbosch University. marthemaleke@yahoo.fr., ORCID: https://orcid.org/0000-0002-5251-7744 